\title{
Risk factors for complications of implantable venous access port usage among young pediatric patients with a solid tumor in China: a single-center retrospective study
}

\author{
Shanshan $\mathrm{Qiu}^{1}$, Ming $\mathrm{Hu}^{1}$, Ping Guan ${ }^{1}$, Chenchen $\mathrm{Li}^{1}$, $\mathrm{Nan} \mathrm{Bao}^{1}$, and Jun $\mathrm{Chu}^{1}$ \\ ${ }^{1}$ Shanghai Childrens Medical Center Affiliated to Shanghai Jiaotong University School of \\ Medicine
}

October 22, 2020

\begin{abstract}
Background and Objectives: This study aimed to evaluate the utilization of totally implantable venous access ports (TIVAPs) and identify risk factors for complications associated with their usage in young pediatric patients with a solid tumor. Methods: We retrospectively investigated the clinical characteristics and procedure records of all patients admitted with a solid tumor who underwent TIVAP implantation and removal as well as line patency maintenance in our clinic from 2016 to 2019 at the Shanghai Children's Medical Center. Results: Overall, 144 patients were evaluated over 28,444 catheter days. There was a greater risk of central line-associated bloodstream infection (CLABSI) in patients with neuroblastoma who were older in age and whose body mass index was lower. The rate of CLABSI was relatively increased in high-risk than low-risk and intermediate-risk neuroblastoma according to the Children's Oncology Group (COG) classification system. There were no significant differences in complications between the TIVAP implantation group and the combined surgery group. Conclusions: Older age, lower BMI, and high COG risk are great risk factors of CLABSI in patients with neuroblastoma, thus requiring vigilant surveillance. Combining TIVAP insertion with biopsy and/or resection surgery should be given due consideration.
\end{abstract}

\section{Hosted file}

1021 Risk factors for complications of TIVAP.pdf available at https://authorea.com/users/ 369394/articles/488267-risk-factors-for-complications-of-implantable-venous-accessport-usage-among-young-pediatric-patients-with-a-solid-tumor-in-china-a-single-centerretrospective-study 


\section{Complication rates}

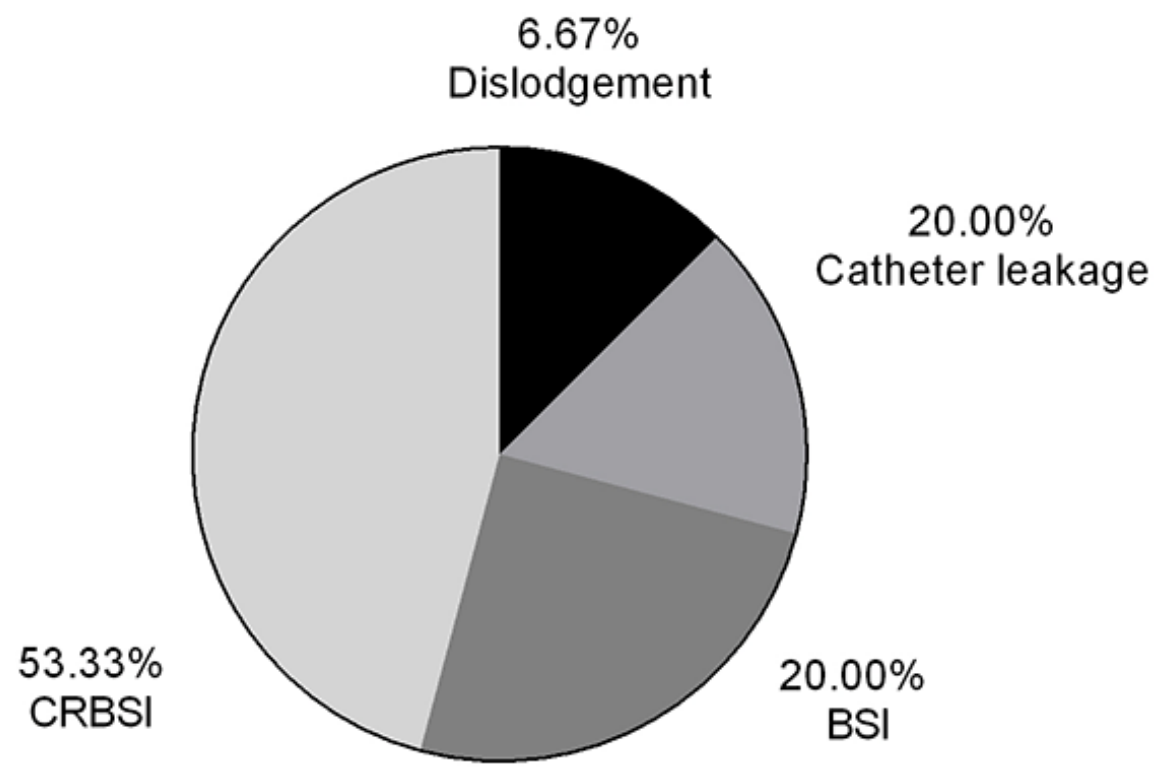

\section{Hosted file}

Table 1.pdf available at https://authorea.com/users/369394/articles/488267-risk-factors-forcomplications-of-implantable-venous-access-port-usage-among-young-pediatric-patientswith-a-solid-tumor-in-china-a-single-center-retrospective-study

\section{Hosted file}

Table 2.pdf available at https://authorea.com/users/369394/articles/488267-risk-factors-forcomplications-of-implantable-venous-access-port-usage-among-young-pediatric-patientswith-a-solid-tumor-in-china-a-single-center-retrospective-study

\section{Hosted file}

Table 3.pdf available at https://authorea.com/users/369394/articles/488267-risk-factors-forcomplications-of-implantable-venous-access-port-usage-among-young-pediatric-patientswith-a-solid-tumor-in-china-a-single-center-retrospective-study

\section{Hosted file}

Table 4.pdf available at https://authorea.com/users/369394/articles/488267-risk-factors-forcomplications-of-implantable-venous-access-port-usage-among-young-pediatric-patientswith-a-solid-tumor-in-china-a-single-center-retrospective-study

\section{Hosted file}

Table 5.pdf available at https://authorea.com/users/369394/articles/488267-risk-factors-forcomplications-of-implantable-venous-access-port-usage-among-young-pediatric-patientswith-a-solid-tumor-in-china-a-single-center-retrospective-study

\section{Hosted file}

Table 6.pdf available at https://authorea.com/users/369394/articles/488267-risk-factors-forcomplications-of-implantable-venous-access-port-usage-among-young-pediatric-patients- 
with-a-solid-tumor-in-china-a-single-center-retrospective-study 